\title{
LA DISONANCIA Y OTRAS DESVIACIONES DEL DISCURSO EN LA POÉTICA LITERARIA, MUSICAL Y GESTUAL DEL CULTO A LA RAZÓN. (DE LA NORMA DE ZARLINO A LA GESTUALIDAD DE LA ZARABANDA)
}

\author{
LUCÍA DÍAZ MARROQUÍN \\ The Warburg Institute
}

\section{RESUMEN}

La cosmología humanista europea se basa en la idea de una coherencia macrocósmica - la armonía de las esferas-, que se refleja en el ámbito microcósmico humano de la poética literaria, musical o gestual. La existencia misma de la disonancia, como metáfora o como hecho, cuestiona el concepto humanista y prerracionalista del decoro poético hasta lo más profundo.

Entre 1550 y 1700, las categorías de los afectos éticos y de las pasiones indecorosas se oponen entre sí hasta acabar siendo asimiladas bajo el culto a la Razón. En este mismo período, los autores literarios y musicales, además de intérpretes de todo tipo, desde los que ponen en escena cualquiera de las múltiples variedades de drama musical hasta los bailarines, exploran los límites del universo pasional subvirtiendo así el decorum convencional basado en la idea de consonancia. El uso de la disonancia literaria, musical o gestual es uno de sus instrumentos poéticos y retóricos más efectivos.

Palabras clave: Disonancia, consonancia, decorum, afectos, pasiones, erotismo, Aristóteles, Gioseffo Zarlino, Torquato Tasso, López Pinciano, Bances Candamo, Athanasius Kircher, Claudio Monteverdi, Pietro Cerone, Andrés Lorente, Pablo Nasarre, Marie Catherine d'Aulnoy, zarabanda.

\section{DISSONANCE AND OTHER DISCOURSE DEVIATIONS IN THE LITERARY, MUSICAL AND GESTURAL POETICS OF THE CULT OF REASON}

\begin{abstract}
The European early-modern poetic and rhetorical cosmology supports itself on the idea of a macrocosmic coherence - the harmony of the spheres-, reflected in the microcosmic-human literary, musical or gestural poetics. However, the phenomenon of dissonance, both as metaphor and as fact, challenges the humanist and pre-rationalist poetic decorum.

Between 1550 and 1700, the categories of the ethical affects and the indecorous passions struggle to find some balance, which they ultimately achieve under the cult of Reason. Meanwhile, literary and musical authors, as well as performers of every kind, from textual or musical drama to dance, explore the limits of the passionate emotions by means of disrupting the conventional decorum based on the idea of consonance. The use of literary, musical and gestural dissonance is one of their preferred poetic and rhetorical tools.
\end{abstract}

Key words: Dissonance, consonance, decorum, affects, passions, erotism, Aristotle, Gioseffo Zarlino, Torquato Tasso, López Pinciano, Bances Candamo, Athanasius Kircher, Claudio Monteverdi, Pietro Cerone, Andrés Lorente, Pablo Nasarre, Marie Catherine d'Aulnoy, sarabande. 


\section{LA DISONANCIA Y OTRAS DESVIACIONES DEL DISCURSO EN LA POÉTICA LITE- RARIA, MUSICAL Y GESTUAL DEL CULTO A LA RAZÓN ${ }^{1}$}

Los tópicos de la virtud retórica y la desviación aparecen de forma recurrente tanto en la tratadística latina sobre oratoria, poética o música, como en la que, a partir del auge del humanismo, reescribe la teoría de los clásicos acerca de todos los aspectos del drama o de la realidad pseudodramática que resultan poéticos ${ }^{2}$ o performativos. La virtud, equivalente convencional de la rectitud, la claridad o la perspicuitas, se refleja tanto en los discursos textuales como en los musicales o gestuales que pretenden reproducir el topos de la armonía de las esferas, presente en la literatura platónica y pseudohermética que la Europa humanista conoce prácticamente de forma simultánea ${ }^{3}$. Frente a ella, la desviación aparece en todos los lugares donde existen retorcimiento u oscuridad, características que, sin embargo, terminarían formando parte del decorum poético a medida que el humanismo evolucionara hacia la sofisticación barroca. Los tópicos de la rectitud y la desviación aparecen reflejados en formas diversas dependiendo de si se trata de un tipo de discurso o de otro: si en el ámbito poético textual, tanto los comentaristas modernos de Aristóteles, como los italianos Robortello o Minturno o sus receptores en otros paí-

${ }^{1}$ En este artículo utilizaré el término Razón (con mayúscula) en aquellos casos en los que me refiera a fuentes o autores racionalistas que lo escriben sistemáticamente así. En todos los demás casos, por ejemplo en las referencias tomadas de la literatura aristotélica o prerracionalista, opto por la ortografía convencional que lo escribe con minúscula.

${ }^{2}$ Utilizo aquí el término en el significado original del verbo $\pi$ oté $\omega$, relativo a cualquier forma de discurso con pretensiones activas.

${ }^{3}$ Alrededor del año 1460, uno de los monjes que actuaban como agentes bibliográficos al servicio de Cosimo de' Medici trajo consigo desde Macedonia un manuscrito que contenía catorce de los quince tratados de los que se suponía compuesto el Corpus hermeticum ancestral. El interés que despertó este corpus sobrepasó al que habían despertado los tratados de Platón, que Marsilio Ficino, también al servicio de Cosimo de' Medici, estaba a punto de traducir. Fue el mismo Cosimo quien ordenó retrasar la puesta al día de la obra del filósofo griego para comenzar inmediatamente la traducción de la obra atribuida al Termaximus Priscus Theologus. El corpus resultante de la traducción de Ficino, conocido a partir de entonces como Pimander - el comentarista italiano extiende el título del primer tratado del manuscrito original a todos los demás- establece la genealogía de la sabiduría en la que se basan gran parte de los tratados humanistas dedicados a la capacidad creativa del hombre. Desautorizada ya por Isaac Casaubon en 1614 la datación arcaica del Corpus, la influencia de la literatura pseudohermética explica sin embargo parte de los supuestos en los que se basa el conocimiento preenciclopédico y enciclopédico que va surgiendo a medida que se extiende por Europa el culto a un tipo de Razón más centrada en el conocimiento fisiológico que en el esoterismo mágico. La teoría racionalista espiritualista que surge con la Contrarreforma asume igualmente muchas de las ideas herméticas, aunque lo haga pretendiendo sistemáticamente fundirlas o asimilarlas a los principios cristianos. Resulta paradigmática, en este sentido, la teoría del gesto retórico que Juan Caramuel Lobkowitz desarrolla en su Trismegistus Theologicus (Trismegistus Theologicus latine cuius tomi sunt tres: in quibus tres virtuales et morales maximae, quae subcollant Restrictionum doctrinam radicitux edisseruntur, Vigebano, Typis Episcopalibus apud Camillum Conradam, 1679). 
ses de Europa, habían puesto de manifiesto la necesidad de ceñirse a convenciones estilísticas basadas en la idea de la claridad, también en ámbitos como la música o la danza se reflejan las mismas convenciones éticas que sirven de guía a los tratados de poética textual. La oposición consonancia/disonancia resulta así paralela al binarismo retórico dolcezza/asprezza, muy significativo en los años en los que se desarrolló la Questione della lingua italiana y tuvo lugar la dignificación progresiva de los distintos romances europeos ${ }^{4}$. Por otra parte, esta misma oposición equivale a la que se establece entre las ideas equilibrio y desequilibrio fisiológico o fisionómico (gestual), de resonancias hipocráticas y galénicas, que tanta influencia alcanzaría a partir del momento en el que los tratadistas interesados por la práctica escénica barroca comenzaran a prestar atención a la dimensión significativa del gesto, y esto a pesar de que el fuerte sustrato misógino que anima gran parte de sus reflexiones puede velar su significado ante nuestros ojos hoy en día.

El término disonancia viene siendo empleado de una manera ambigua desde hace siglos, aunque esta ambigüedad se ha acrecentado en los últimos años a causa del uso metafórico que hace de él la literatura filosófica francesa. Su significado estrictamente musical describe el fenómeno por el que dos sonidos producidos al unísono dan lugar a intervalos caracterizados por un reducido grado de estabilidad y, como consecuencia, desagradables para el oído humano. La definición de qué intervalos deben considerarse disonantes no ha resultado unívoca a lo largo del tiempo, sino que ha variado mucho desde la fijación del sistema musical occidental. En principio, sólo la quinta justa y la octava podrían considerarse como consonancias perfectas, mientras que existen numerosas discrepancias entre los músicos teóricos y los prácticos sobre la consideración de otros intervalos. Así, Boecio define las terceras y sextas mayores y menores como disonancias a causa de la complejidad de sus ratios (81/64 para la tercera mayor o ditono, y 32/27 ó 19/16 para la tercera menor o semiditono), lo que no impide que los polifonistas las utilicen como consonancias imperfectas en el contrapunto. Intervalos como la cuarta aumentada (tritono) o la segunda menor han mantenido su carácter disonante a lo largo de los siglos al menos hasta la emancipación de la disonancia, ya en tiempos de Schoenberg. Por último, los teóricos modernos vacilan acerca de la consideración de la cuarta justa o diatessaron como consonante o disonante dependiendo de si aparece o no subrayada por el tercer o el quinto grado del acorde, hasta llegar a su admisión definitiva en el paradigma de la consonancia perfecta. El significado psicológico del término disonancia, articulado mucho más recientemente, tiene que ver con la «disonancia cognitiva», un

${ }^{4}$ VEGA RAMOS, María José. Analiza los conceptos de qualitas sonorum y sus derivados (dolcezza, asprezza, voluptas aurium y otros) en El secreto artificio. Maronolatría y tradición pontaniana en la poética del Renacimiento. Madrid: CSIC/Universidad de Extremadura, 1992. 
fenómeno por el que, ante realidades o conductas que contradigan el paradigma mental previo de un sujeto, éste articularía vías que le permitan explicarse su nueva realidad mediante conceptos no necesariamente basados en los hechos que conoce, aunque sí provisionalmente funcionales, ya que le permiten enfrentarse momentáneamente al dolor de lo «no conocido» ${ }^{5}$. Por último, la disonancia poética resume aproximadamente el significado de los dos conceptos anteriores, incorporando la noción de desagrado ante realidades o términos coexistentes aunque difícilmente comprensibles cuando se presentan de forma simultánea.

Tanto los autores clásicos latinos como los que asumen su herencia en la Europa humanista suelen ceñirse a una disposición convencional de la jerarquía de los sentidos en la que la vista ocuparía el primer lugar, seguida por el oído, el gusto, el olfato y, por último, el tacto ${ }^{6}$. Sin embargo, la práctica generalidad de los tratadistas de música y muchos de los que se ocupan de la poética dedican algo de esfuerzo a glosar la prevalencia del sentido del oído. Desde este punto de vista, es precisamente la posibilidad de ejercer una influencia moral a través del oído la que situaría a la música y a la enunciación poética por encima de la pintura, la otra disciplina artística que más frecuentemente aparece comparada con las posibilidades expresivas de la retórica ya desde la interpretación extracontextual del tópico horaciano «ut pictura poesis» ${ }^{7}$ :

${ }^{5}$ El término «disonancia cognitiva» fue propuesto en 1956 por el psicólogo Leon Festinger. FESTINGER, Leon; RIECKEN, Henry W. y SCHACHTER, Stanley. When Prophecy Fails, A Social and Psychological Study of a Modern Group that Predicted the End of the World. Minneapolis: University of Minnesota Press, 1956.

${ }^{6}$ Es el orden que defiende Aristóteles en De sensu. La vista es el sentido preeminente, aunque, teniendo en cuenta que la principal forma de difusión del conocimiento en su tiempo es la oral, no puede dejar de señalar al menos algún aspecto por el que el sentido del oído resulta menos prescindible para la inteligencia que la vista. ARISTÓTELES. De los sentidos. I, 437 a.

${ }^{7}$ La equiparación de las cualidades visivas de la imitación poética con las que sugiere la pintura según una interpretación demasiado apresurada $-\mathrm{y}$, en todo caso, descontextualizada - de la proposición horaciana resulta sin embargo tentadora. La comparación de la poesía con la pintura es un tópico clásico que aparece ya, por ejemplo, al comienzo de la Poética aristotélica (47a. 18) y en la equiparación del gusto por la consonancia musical con la preferencia por determinados colores en De sensu III 439b. Tanto las retóricas de Cicerón y Quintiliano como los comentaristas aristotélicos del siglo XVI se sirven del símil (sobre la presencia del tópico visivo en las retóricas clásicas latinas véase C. FISKE, George. Cicero's «De Oratore» and Horace's «Ars Poetica». Wisconsin, Madison: Universiy of Wisconsin, 1929, 135). Al mismo tiempo, desde la otra orilla de la tratadística, la de la reflexión humanista sobre las artes plásticas, tiene lugar un fenómeno simétrico de fascinación con los procedimientos retóricos, así como un intento de adecuación de los principios de la composición pictórica a los de la inventio, dispositio y elocutio retóricas. Véase, sobre el error en la interpretación del «ut pictura poesis», GARCÍA BERRIO, Antonio. Formación de la teoría literaria moderna. Tópica horaciana. Renacimiento europeo. Madrid: Cupsa, 1977, pp. 293; y también GARCÍA BERRIO, Antonio. Introducción a la poética clasicista. Madrid: Taurus, 1988, pp. 60-65. 
«Únicamente la música educa no sólo con la palabra, sino también con imágenes de las acciones, y no lo hace mediante imágenes inmóviles o fijas en una única figura corporal, sino mediante imágenes animadas que modifican su forma y su movimiento en íntima unión con cada uno de los hechos que se narran. Esto queda claro tanto a partir de la danza de los coros antiguos, cuya directora era la rítmica, como de lo que han escrito muchos autores sobre la representación escénica. Ciertamente, aquellas artes que tienen sus propias materias específicas no pueden conducirnos rápidamente al concepto de la acción. En efecto, mientras que en unos casos los colores, en otros los volúmenes y en otros la palabra suponen cosas ajenas a la verdad, la música persuade con la mayor eficacia, pues hace la imitación con cosas similares a aquéllas con las que se realizan también las mismas acciones de verdad» ${ }^{8}$.

Las huellas de las tradiciones aristotélica y horaciana aparecen en este fragmento del De musica de Arístides Quintiliano traducidas en los conceptos de acción poética («imágenes inmóviles o fijas en una única figura corporal») y de acción de verdad. El código de la palabra poética, el del concento musical —expresados ambos mediante la modulación de la voz- y los ritmos de la danza, que contribuyen a la formación de significado mediante la retórica del gesto, resultan así inseparables desde el punto de vista de la imitación de las condiciones éticas y las pasiones del alma:

«Efectivamente, puesto que en los hechos que acontecen la voluntad va en primer lugar, le sigue la palabra y tras ello se realiza la acción, la música imita los éthe y las pasiones del alma con los conceptos, las palabras con las armonías y la modulación de la voz, y la acción con los ritmos y el movimiento del cuerpo. Por todo ello, una educación de este tipo debe estar dirigida principalmente a los niños, para que mediante las imitaciones y las semejanzas realizadas en la infancia lleguen a conocer y desear a través del hábito y el ejercicio las cosas que en la edad adulta se realizan en serio»?

La teoría aristotélica que recogen los tratadistas latinos de retórica y poética resulta esencialmente binaria y se articula en función de la existencia de dos clases de hombres: los mejores y los peores «en cuanto al vicio». Ambas clases experimentarán la catarsis de forma diferente: los primeros, comprendiéndola de forma distanciada al observar los acontecimientos dramáticos; los segundos, dejándose arrebatar incluso físicamente por estos acontecimientos y experimentando la sacudida de las emociones que ven experimentar a otros. La igualmente tradicional división aristotélica entre el entorno de las pasiones — vehementes y perturbadoras - y el de la razón plantea conflictos a la hora de distinguir el camino de lo virtuoso que se reflejarán en la mayoría de las teorías sobre el estilo que ponen en pie los tratadistas a lo largo de los siglos siguientes. Cuando en la Europa moderna los poetas, compositores, teóricos e intérpretes que colaboran para la dignificación de las lenguas verná-

\footnotetext{
${ }^{8}$ QUINTILIANO, Arístides. De Musica, II, 4.

${ }^{9}$ Ibid. II, 4.
} 
culas intenten dilucidar el papel de la emoción y las formas de expresarla se pondrá de manifiesto hasta qué punto la poética y la ética resultan indisolubles. Asumida la división tradicional entre pasión y razón, pero observando la evidencia de que, sin la presencia de la emoción, no existe discurso poético posible, uno de los primeros puntos de conflicto a los que deberán enfrentarse será el distinguir aquellas emociones que resultan éticas o decorosas de aquellas otras que exceden el ámbito de lo poéticamente admisible. Así surgirá una terminología que implica la clasificación de las emociones en dos categorías principales a uno y otro lado de la línea de la mesotes: se hablará de afectos para referirse a las emociones éticas, temperadas por la razón, mientras que las pasiones conservarán su aura de oscuridad y amenaza. Aun así, la distinción entre lo que es afecto y lo que es pasión tarda en estabilizarse. De hecho, la confusión entre ambos términos resulta frecuente al menos hasta el auge del Racionalismo. La clasificación general convive con otras particulares de menor éxito, como la que propone Minturno en su Arte poetica de 1564, que divide la categoría general de los afectos en costumi (equivalentes al habitus, o emociones éticas) y las pasiones propiamente dichas:

«Ma, perche degli affetti altri sono impetuosi, e gravi, e pungenti; altri piacevoli, e soavi, e leggieri, da'rhetorici passioni quelli si chiamano, e questi costumi. Questi vagliono ad acquistar benivolenza ò perdono. Quegli à destare odio, ira, invidia, timore. Questi raccommandono, pregano, iscusano, appagano. Quelli turbano, commandono, sospingono, infiammano. Io stimo tra costumi e le passioni esser quella differenza, la qual'è tra gli habiti dell'animo, et i turbamenti» ${ }^{10}$.

A pesar de partir de la clásica consideración de las pasiones como ceguera del entendimiento, subrayada en el universo católico por la literatura moral postridentina, el hecho es que los autores e intérpretes de obras poéticas, desde la poesía textual hasta el drama musical, no tardan en experimentar la contradicción de que es precisamente el territorio de la pasión el que plantea una auténtica tentación creativa y el que despierta el mayor interés del público. No resulta extraño, por lo tanto, que la tendencia en la teoría poética elaborada en los distintos países que sucumben a la influencia italiana sea la de transgredir los límites éticos que separan lo afectivo de lo pasional. La creciente confusión de términos en este tipo de literatura revela una superación implícita de la tópica oposición clásica entre el universo ético (el terreno del encauzamiento de lo afectivo mediante la disciplina del habitus) y el desbordamiento patético que, sobre el escenario teatral, da lugar el efecto dramático de la catarsis. La confusión alcanza su punto más alto en la literatura racionalista, aunque, en realidad, se trata de un fenómeno anterior: según observa López Pinciano en la «Epístola primera que trata de la felicidad humana» de su Philosophía antigua poética de 1596 «aquella perturbación del ánimo es

${ }^{10}$ MINTURNO, Antonio Sebastiano. L'arte poetica. Venecia: G. Andrea Valvassori, 1564. 48. 
la que se dice afecto y passión, la cual es indiferente en el hombre a seguir al apetito o a la voluntad; que, si esta perturbación se une con lo irracional, queda hecho apetito $\mathrm{y}$, si con lo racional, se convierte en virtud ${ }^{11}$. Como tantos otros autores en los años inmediatamente posteriores a Trento, López Pinciano decora su discurso mediante el desarrollo de la metáfora bélica, presente ya en el libro de Job pero especialmente característica de la ascesis ignaciana, a propósito de la búsqueda de la virtud como una batalla entre los escuadrones del apetito y de la voluntad:

«Y, pues habemos de entrar en esta batalla, conviene empezar a ordenar los escuadrones, de quienes los caudillos principales son el apetito y la voluntad, compañera de la razón buena. Si ésta vence, queda hecha la paz de la virtud y, si es vencida, queda la guerra y la semilla de toda discordia, que es el vicio. Y esto es así, porque, como dice el Philósopho, la razón tiene imperio real sobre el apetito, que es decir, mándale con justa justicia y él es obligado como vasallo a la prestar obediencia. (...) Veis adonde la razón habla con la irascible. Pero, si manda el apetito a la razón, queda él hecho tirano y como tal no sustiene en paz a su República, antes la da ocasión de nuevas lides. Digo, en suma, que el apetito como tirano señorea a la razón; y, atendiendo a su particular gusto, acocea a todo lo que es razón y justicia, más la razón buena, autora de la buena voluntad, es una reina, la cual sólo atiende y pretende el pro común y bien universal de la República. (...).

¿Por qué llamáis apetito al del hombre y no voluntad?

Fadrique respondió:

- Si yo dijera apetito del alma, dijera voluntad; mas digo de hombre y así conviene decirle apetito, porque el hombre le tiene indiferente y puede seguir el intellectual y del alma, dicho razón; y puede seguir el de bestia, dicho apetito irracional. El hombre, cuerpo y alma junto, es el campo desta batalla; que apartado el uno del otro, no hay lid ni tampoco virtud ni vicio. Hombre ha de ser en quien haya apetito y haya razón para que haya guerra, producidora de las virtudes y vicios; que el alma, separada y apartada del cuerpo, no es liberal ni templada y el bruto no es templado ni liberal, como el muchacho en tanto que la razón no tiene fuerza bastante para lidiar con su contrario, el apetito» ${ }^{12}$.

Resulta muy representativa la clasificación que hace López Pinciano de las pasiones, dependientes de las potencias irascible y concupiscible, y de sus contrarios. A pesar de proceder de la herencia aristotélica, su clasificación ha evolucionado mucho más allá de los dos afectos catárticos primarios de la compasión y el miedo:

«El apetito se divide en dos escuadras: a la una dicen irascible y a la otra, concupiscible. Irascible se dice aquella potencia que tiene por objeto lo arduo y dificultoso y por fin, el gozo. Concupiscible, la que tiene por objeto lo deleitoso y por fin, también el gozo. De la una y de la otra el fin es uno; y aun el objecto

${ }^{11}$ LÓPEZ PINCIANO, Alonso. Philosophía antigua poética. 42-44.

${ }^{12}$ Ibid. 52-53. 
también realmente, que es lo bueno. Distínguense en que la concupiscible sólo atiende a lo bueno como bueno, y la irascible lo mira como dificultoso y arduo. Quiérome declarar con un ejemplo: el amor, considerado simplemente como un deseo de gozar la cosa amada, toca a la parte concupiscible; pero, si se considera en cuanto está acompañado con la esperanza o desesperación, compete a la irascible.

Esto se entenderá mejor, si digo los soldados con que cada una de las potencias o escuadras milita, los cuales son dichos afectos y passiones, como antes fue dicho; de los cuales digo así, según el orden de su generación: son los primeros amor y odio, y luego, deseo, huida, esperanza y desesperación, temor y osadía y ira; y más, el gozo y la tristeza, las cuales acompañan a las demás passiones todas. Las primeras cuatro (que son amor y odio, deseo y fuga) son soldados de la concupiscible y las otras cinco (esperanza, desesperación, temor y osadía y ira) pertenecen a la irascible; y el gozo y la tristeza, a la una y a la otra. Todas tienen sus contrarios, salvo la ira» ${ }^{13}$

Los esfuerzos por delimitar el ámbito de la razón y el aspecto de las emociones se reflejan en la obra de numerosos tratadistas de poética en toda Europa. Aun así, nada resulta tan ajeno a la expresión artística como la sujeción a criterios exclusivamente racionales. La pretensión de originalidad viene siendo una constante en la configuración de los discursos poéticos, tanto si se trata de discursos literarios como musicales o gestuales, y tanto si éstos se presentan en forma oral como si lo hacen en forma gráfica o sonora, al menos desde los tiempos en los que, con la generalización de la imprenta, el conocimiento en forma escrita perdió parte de su consideración minoritaria y pasó a ser considerado como un bien de consumo aproximadamente generalizado. El recurso al criterio de la novedad como medio para despertar la atención de mecenas o públicos resulta así tan efectivo en las primeras décadas del siglo XVII en las que se extiende por Europa la monodia vocal con acompañamiento de bajo continuo sobre textos poéticos o libretos dramáticos como pueda serlo hoy en día, cada vez que tiene lugar el estreno de un espectáculo, o cada vez que la adjudicación de un premio literario a una determinada obra o autor recuerda a los posibles receptores/consumidores —interactividad audiovisual mediante- la necesidad de poseerla intelectual o materialmente. Sin embargo, la alternancia entre la solidificación canónica y su tendencia gemela, el ansia de ruptura de los cánones preestablecidos, especialmente cuando éstos fueron impuestos, resulta tan constante en la configuración de discursos con pretensiones artísticas como la misma pretensión de novedad que manifiestan muchas de las primeras ediciones de obras poéticas puestas en música que la imprenta publicó en sus primeros tiempos. Y si, en los años en los que tuvieron lugar los primeros intentos maduros de fundir la palabra literaria con la música y el gesto dramático en función de una intención retórica, primero en el repertorio de la canción polifónica y, poco después, en el del drama musical, existió una lucha constante entre el canon poético y su

\footnotetext{
${ }^{13}$ Ibid. 54-56.
} 
subversión mediante elementos discursivos ajenos a las cualidades defendidas por los teóricos (claridad, inteligibilidad, perspicuitas, vigor), ésta consistió en el uso de la disonancia con valor retórico afectivo.

Frente a la búsqueda constante de la concordia y el establecimiento de valores poéticos acordes con los perfiles de la virtud y el ethos defendidos por Gioseffo Zarlino y otros tratadistas italianos inspirados directamente en el ideal platónico de la música de las esferas, la disonancia, inicialmente repudiada por los teóricos y admitida sólo como un mal necesario en el discurso contrapuntístico de la música de órgano, lucha durante décadas por ser aceptada como técnica expresiva, especialmente en los momentos y entornos en los que los autores persiguen la expresión poética de lo pasional. Tras una temprana generación de polifonistas italianos y franco-flamencos que asimilan al madrigal moderno las técnicas del contrapunto imitativo clásico, entre ellos Jacobus Arcadelt o Constanzo Festa, la primera generación de autores ya plenamente seguros de su dominio de las técnicas contrapuntísticas es la que agrupa a algunos como Pomponio Nenna, Carlo Gesualdo, Lucca Marenzio, Giaches de Wert o Luzzasco Luzzaschi. Estos compositores, educados en el ambiente que permite el desarrollo de la Questione della lingua e incluso personalmente familiarizados con defensores del italiano como lengua poética como Torquato Tasso o Giovan Battista Marino, se atreven ya a jugar con recursos basados en la fragmentación de las imágenes poéticas presentes en el texto, o bien con otros derivados de la representación de los afectos mediante cromatismos y otros efectos retóricos sumamente audaces. Los comentarios que Tasso vierte en su diálogo Cavaletta, ovvero della poesia toscana acerca de la musica lasciva, como opuesta a la musica temperata reflejan la actitud estética de esta generación de poetas y madrigalistas anterior a $1600^{14}$. Sin embargo, el combate entre las posturas más conservadoras y la defensa de la disonancia o asprezza como método de expresión afectiva sólo alcanzaría su punto de máximo fragor años después de que, sobre los principios del stile rappresentativo, llegara a desarrollarse el stile a voce sola que permitiría finalmente el surgimiento y posterior diseminación por Europa del dramma per musica. El siempre polémico Claudio Monteverdi actúa más como catalizador que como provocador para los ataques que dirigen los estamentos conservadores a los creadores de nuevos medios expresivos basados en la ruptura de la norma zarliniana. Como señala Lorenzo Bianconi, al menos en lo que respecta al uso de la disonancia, Monteverdi es más el continuador de una tendencia ya antigua que un renovador a ultranza ${ }^{15}$. La defensa del efecto retórico-afectivo de la disonancia o asprezza frente a la reivindicación del contrapunto zarliniano

${ }^{14}$ TASSO, Torquato. La Cavaletta overo de la poesia toscana. Tasso. Dialoghi. 2 vols. Baffetti, Giovanni (ed.); Raimondi, Ezio (intr.). Milano: Rizzoli, 1998. vol. II, pp. 707-708.

15 BIANCONI, Lorenzo. Il secolo XVII. Historia della musica. Turín: E.D.T., 1977, pp. 21-22. (Ed. española: Historia de la Música, 7 vols. Madrid: Turner, 1992, vol. III. 
que ejercen los conservadores, personificados en Italia en la figura de Giovanni Maria Artusi y, en países como España, en toda una tradición de tratadística musical que cuenta con una de sus presencias más relevantes en los De musica libri septem de Francisco Salinas, resulta ser, en el fondo, una polémica algo desfasada entre quienes tienen ya plenamente asumida la consideración de la disonancia como recurso expresivo, si bien han dejado atrás el estilo abrupto y algo epigramático característico de los madrigales de Carlo Gesualdo, y los que, por el contrario, defienden el retorno a la virtud retórica basada en la consonancia, la inteligibilidad y la verticalidad, materializadas en el discurso musical del stile alla Palestrina.

La recepción del valor estético de la disonancia resulta tardía y desigual en España con respecto a las innovaciones de los italianos practicantes de la seconda prattica. Su equiparación con la falsedad o la impropiedad poética cuenta con una larga tradición incluso en las compilaciones de obras que muestran una deuda explícita con la estética italiana, como es el caso de los Tres libros de música para vihuela que Alonso Mudarra publica en $1546^{16}$. El conocido comentario a propósito de los cromatismos e intervalos inusuales de la «Fantasía que contrahace la harpa en la manera de Ludovico» que Mudarra introduce («Desde aquí hasta acerca del final hay algunas falsas; tañiéndose bien no parecen mal») tiene sentido precisamente en función de este tópico de la equiparación de la disonancia con la desviación poética, reforzado en este caso al aparecer los tres libros bajo la advocación de Hermes, dios de la Retórica, representado en un grabado en el que se le atribuye la invención de la lira. También el italiano de origen aunque español de adopción Pietro Cerone, partiendo de un símil retórico muy significativo por su referencia explícita a las dimensiones fisonómicas de la oratoria ${ }^{17}$, utiliza el término disonancia asimilándolo a un error en la lectura musical del contrapun-

${ }^{16}$ Además de las obras italianas que pudiera conocer durante su formación en la casa de los duques del Infantado, Mudarra pudo pasar una breve estancia en Italia acompañando al tercero de ellos, Iñigo López de Mendoza, como parte del séquito del emperador Carlos V. Su interés por la equiparación del estilo poético español y el italiano queda claro, además, en la convivencia en el tercero de sus libros de obras poéticas de autores italianos como Petrarca (MUDARRA, Alonso. «La vita fugge». Tres libros de música para vihuela. Sevilla. Juan de León, 1546. III, XXXVI-XXXIX) o Sannazaro, («O gelosia d'amanti». Ibid. III, XLIv-XLIV y «Itene al'ombra» III, XLIV-XLV) con otras de autores castellanos como Manrique («Recuerde el alma dormida» Ibid. III, XX-XXI); Boscán («Claros y frescos ríos» Ibid. III, XXI-XXIII) o Garcilaso («Por ásperos caminos» Ibid. III, XXVIII-XXX).

${ }_{17}$ «Que assi como al Orador se requiere y conviene no solamente la gracia de la habla con la que diga y explique su concepto, mas los meneos, los gestos, y las acciones con que sus conceptos sean bien declarados y explicados, assi también se requieren al Cantor, por tener nombre de cumplido y perfeto». CERONE, Pietro. «De algunos vicios ò deffetos que se toman por inavertencia y mal uso», «Preámbulo». El Melopeo y Maestro, Tractado de música theorica y practica, en que se pone por extenso lo que uno para hazerse perfecto Musico ha menester saber, y por mayor facilidad, comodidad y claridad del Lector, esta repartido en XXII Libros. Nápoles: Juan Bautista Gargano y Lucrecio Nucci, 1613. 68. 
to polifónico y no, como pudiera parecer, a la presencia de una disonancia real entre las voces. Utilizando un tipo de humor muy característico de la literatura prerracionalista y racionalista europea, observa además cómo la aparición de este tipo de descomposición en el entramado polifónico suele dar lugar a disarmonías similares en la fisonomía de los cantores, en este caso en forma de muecas admonitorias:

«Ni menos quiero callar el biasmo de aquellos los quales luego en sentiendo el compañero que por no pronunciar a tiempo, tocó alguna dissonancia, echan los ojos sobre del, a fin que todos los presentes lo sepan, que hizo error» ${ }^{18}$.

En 1672, Andrés Lorente recoge el tópico de la asociación entre la disonancia y la desviación retórica, aunque, al contrario de otros tratadistas, se muestra dispuesto a admitir el valor estético de las especies dissonantes, falsas, ò malas aunque sea como contraste capaz de realzar la consonancia:

\begin{abstract}
«pues son tan necessarias en la Musica, para su perfeccion, por quanto con la variedad de especies, perfectas, imperfectas, y falsas, se haze más harmoniosa, y perfecta, por hallarse más variacion en ella; y con las unas, y las otras especies, se ocasiona mucha diferencia, y se hazen muchos primores Musicos (...) Y se note que este nombre, Falsa, se tomó del verbo Fallo, que es engañar, por quanto estas especies falsas, son tan alagueñas, y se introducen en la consonancia con tanta suavidad en sus principios, que si después no se sabe usar de ellas en la misma consonancia, o consonancias que se sigue, o siguen, será, o serán destruidas con su dureza de sonido, causando desazón a los oyentes» ${ }^{19}$.
\end{abstract}

Lorente equipara de forma explícita la disonancia al engaño, el monstruo que amenaza la virtud retórica desde los días de la crítica a los sofistas, aunque admite la licencia estética de utilizar la disonancia como contraste útil para proporcionar un mayor grado de evidentia retórica a la consonancia, recurriendo además a los conceptos retóricos del tempus y la occasio ${ }^{20}$. La llamada tópica a la auctoritas aristotélica termina de confirmar las pretensiones de rectitud retórica del pasaje:

«Mas mezclándolas con las especies buenas, buscando ocasión, y tiempo que les convenga, hazen la Música muy dulce, agradable, y sonora, de lo que careciera si no tuviera el uso de estas especies, por quanto no fuera tan dulce, tan agradable, y tan sonora; y assí se le ocasionó el ser a la Música, en hazer esta mezcla de especies, dissonantes, falsas, o malas, con las especies perfectas, imperfectas, y buenas, pues con las unas, y las otras la explanaron, dando ocasión a los infa-

${ }^{18}$ CERONE, Pietro. Ibid. 68.

${ }^{19}$ LORENTE, Andrés. «Arte de contrapunto». El porqué de la música en que se contiene los quatro artes de ella, canto llano, canto de organo, contrapunto, y composición, y en cada uno de ellos nuevas reglas, razón abreviada, en utiles preceptos, aun en las cosas más difíciles, tocantes à la Harmonia Música. Alcalá de Henares: Nicolàs de Xamares, 1672. p. 274.

${ }^{20}$ MUDARRA, Alonso. Tres libros de música para vihuela. XIII-XVIv. 
tigables operarios en ella, a que obrassen con variedad, y primor en todas las Composiciones Músicas»

(...)

«...la dissonancia hace parecer la consonancia, que se le sigue, más deleytosa, y que sea comprehendida mas plausiblemente del oído, assí como después de las obscuras tinieblas, es mas agradable, y deleytosa a la vista la clara luz; y el dulce despues de lo amargo. Esto lo aprueba el Philosopho en el 3. de la Rethorica, diziendo: Opposita, iuxta se posita, magis elucescunt. Y en el primero de los Elencos, dize: Contraria iuxta se posita, maiora, et minora, meliora, et peiora apparent» ${ }^{21}$.

El conservador Pablo Nasarre atiza en 1724/23 los rescoldos de la polémica planteando la cuestión en el «Prólogo al lector» que abre su Escuela musica según la práctica moderna. En unas observaciones muy conocidas, Nasarre se opone específicamente al uso generalizado de la disonancia «introducido en nuestra Nación por algunos Estrangeros»(los italianos), mientras insiste en el antiguo tópico de la denostación de los sentidos - también del sentido del oído- en favor de la facultad racional del alma:

«Dos solos motivos me han estrechado a dar a la pública luz esta Obra; el primero, dar luz en Música, para obrar conforme a razon, por reglas del arte, pues muchos por carecer de escritos, obran, rigiendose solo por la alagueña dulzura del oído. En muchas partes de esta Obra dexo escrito assi el uso de las especies disonantes, como de sus qualidades, y las reglas de como se deven practicar, para que sea buena la Música; pero aviendo reparado que se ha introducido un abuso (no poco pernicioso) que es el valerse de ellas en lugar de especies consonantes, me ha parecido advertirlo en este lugar. El qual abuso se ha introducido en nuestra Nación por algunos Estrangeros, que ya por variar en sus cantinelas, o por no estar en las reglas de buena Musica, han pegado esta enfermedad a muchos de la Nación, los quales no dan otra razón en su abono, sino es que con semejante Música se da gusto» ${ }^{22}$.

La perversión promovida por los estrangeros sólo puede deberse, siempre según Nasarre, a su ignorancia de la teoría de los antiguos:

«No sé que las especies disonantes puedan deleytar al que las oye, y si esto fuera assí no huvieran tenido tanta cuenta los Antiguos, en disponer el como se devian usar, dexándonos reglas para que no se sintiesse su mal efecto» ${ }^{23}$.

Es precisamente en el terreno de la música de una voz sola donde el tratadista aragonés encuentra los mayores atrevimientos, tal y como corresponde a un período en el que, al menos dentro del repertorio vocal dramático, el canto monódico acompañado se había generalizado ya en España:

\footnotetext{
${ }^{21}$ LORENTE, Andrés. «Arte de contrapunto». El porqué de la música, pp. 274-275.

${ }^{22}$ NASARRE, Pablo. «Prólogo al lector». Escuela música según la práctica moderna, 1724/1723. s/f.

${ }^{23} \mathrm{Ibid}$.
} 
«Esta corruptela se halla por comun en Música de una voz sola, poniendo los acompañamientos de ella en especies disonantes en algunos períodos, fuera de las reglas que el Arte tiene dispuestas para su uso. Yo he oído Obras de grandes Maestros Estrangeros, y de la misma Nacion, que los que han introducido este mal uso en España, y estar muy conforme a razon, pero del modo que oy se practica, ni ay razon en su abono, ni oídos que puedan sufrir tal disonancia» ${ }^{24}$.

La traducción de los afectos —o de las pasiones, a partir del momento en el que el que los racionalistas comienzan a dignificar el uso del término- a sonidos vocales y musicales en busca del efecto de la voluptas aurium dentro del perímetro de la verosimilitud mesurada ofrece una gran cantidad de posibilidades expresivas. Sin embargo, como observaba Lope en el Arte Nuevo, si hay algo que caracterice la experiencia artística más allá de las condiciones culturales y temporales en las que se manifiesta es su capacidad de trascendencia: la misma posibilidad que le viene negada por todo planteamiento que prescriba cualquier clase de sujeción a criterios previos más allá de los derivados de las limitaciones o posibilidades de desarrollo del lenguaje o tipo de discurso elegido. En situaciones de constricción excesiva sólo cabe la explosión catártica. Tras la rudimentaria división aristotélica de las pasiones dentro de un ámbito poético en dos únicos tipos (piedad y miedo), sólo desglosada en siete variedades en De anima (suavidad, miedo, piedad, valentía, alegría, amor y odio $)^{25}$, al llegar los siglos XVII y XVIII la cultura afectiva ha evolucionado ya lo suficiente para disgregar las emociones primarias en multitud de afectos codificados de maneras a menudo oscilantes sobre la muchas veces imperceptible frontera que separa el ethos del pathos. Cuando en la Europa del humanismo tardío comience a imponerse el culto a la Razón, también las artes perderán finalmente el miedo a la definición de las emociones como pasiones, a medida que la culpa retórica y poética vaya dejando de

${ }^{24}$ Ibid.

25 ARISTÓTELES. De anima. I.

El segundo motivo al que Pablo Nasarre alude entre los que lo han conducido a componer su obra resulta mucho menos relevante desde el punto de vista del uso de la disonancia en la música española anterior al siglo XVIII. Aun así, para completar el pasaje, lo reproduzco a continuación: «El segundo motivo ha sido la obediencia de los Prelados, en esse superior decreto atendì al mandato de San Tiago en su Epistola cap. I. vers. 19. Sit autem omnis homo velox ad audiendum, tardus autem ad laquendum. Sobre que fue de sentir el ingenioso Alapide hic, fol. 61. In velocitate audiendi, Sanctus Iacobus subintelligit velocitatem obediendi. Y siendo igual precepto la tardanza en el hablar, como para obedecer la velocidad en el oìr, desempeña el mismo Alapide la execucion de mi obediencia en estas bien ponderadas clausulas: Monet ergo Christianos Ordinis, humilitatis, et modestie, ut potius eupiant audire docentes, quam docere audientes: Sapiens enim est, non nisi post multam auditionem, meditationem, et studium prosilire ad docendum, idque tarde, et non nisi rogatum, imò jussum. Recibe pues, Amigo Letor, esta Obra, efecto, no sè, si acertade de sesenta años de exercicio, y cinquenta de Magisterio». NASARRE, Pablo. «Prólogo al lector». Escuela música según la práctica moderna, 2 vols. Zaragoza: Herederos de Diego Larumbe, 1724 y 1723. CSIC, 1980, s/f. (Ed. facs. Zaragoza: Institución Fernando el Católico). 
atenazar la expresión de lo exacerbado. Es el momento en el que, tanto en la pintura como en el repertorio dramático, adquiere legitimidad la expresión desbordada del sentimiento, visible también en la tratadística poética a medida que los términos afecto y pasión empiezan a aparecer como sinónimos.

Tanto el sonido musical como el discurso retórico vocal habían venido desarrollando herramientas para la expresión de las pasiones sobre la escena barroca, pero es el gesto escénico el que completa la experiencia sensorial y afectiva de la colaboración de la palabra poética con la música. Y es la acción —el movimiento visual o la dynamis retórica- más que la experiencia estática, la que consigue finalmente seducir e incluso, desde la perspectiva de los moralistas y de ciertos teóricos dramáticos y musicales, arrastrar a receptores e intérpretes por el desvío de la lascividad. La laxitud y la concupiscencia, incluso cuando se presentan bajo formas estilizadas de poesis erótica suelen aparecer, desde la perspectiva de un sistema moral tendente a una más que discutible noción de bien común, como caminos ajenos a la vía recta de la rectitud moral y de la virtud retórica. Y en la medida en la que el objeto erótico de la poesis masculina resulta ser la mujer, no puede extrañar que sea igualmente la mujer —o su expresión oral, musical y gestual - la que termine convirtiéndose en el icono de toda perversión con respecto a la línea recta de un tipo de virtud y de razón que la ética convencional reserva a los hombres.

Si tanto el discurso retórico de la literatura como el de la música se enfrentan a la necesidad de presentarse como paradigmas técnicos y conceptuales de la rectitud moral en dirección al difuso foco de la virtud, también la retórica del gesto, en su versión discursiva que es la danza, se adscribe al proyecto didáctico-edificante en obras como los Discursos sobre el arte del dançado de Juan de Esquivel (1642). El tratado, dispuesto en siete capítulos, comienza remontando convencionalmente la historia de la danza a la teoría platónica de la armonía de las esferas:

«Y por estos medios he conseguido y alcançado a saber, que en cuanto al origen de la Dança, es cosa indubitable, conforme al sentir de los que della han escrito, que es una imitación de la numerosa armonía que las Esferas celestes, Luzeros y Estrellas fixas y errantes traen en concertado movimiento entre sí» ${ }^{26}$.

Esta armonía universal en la que resuenan los ecos del Somnium Scipionis de Cicerón es la que, mediante un procedimiento mimético con fines éticos, deberían reproducir, según Esquivel, los que aprenden el arte del danzado. Como ejercicio que representa la armonía de la naturaleza y siempre de conformidad con la moral cortesana que aconseja adquirir destreza «en el manejo de las armas, caça de escopeta y montería, hazer mal a un cavallo, pintar y hazer versos, tocar un instrumento...», Esquivel recomienda la danza

${ }^{26}$ ESQUIVEL, Juan de. Discursos sobre el arte del dançado y sus excelencias y primer origen, reprobando las acciones deshonestas. Sevilla: Juan Gómez de Blas, 1642. I, 1r. 
a los personajes más elevados, desde el rey hasta los miembros de la noble$\mathrm{za}^{27}$ ya que «causa tanto luzimiento el dançado en qualquiera persona, que diferencia a las demas assi en la compostura del cuerpo, como en sus movimientos, nivelando de suerte sus acciones, que no le permite alguna que desdiga de la proporcion conveniente ${ }^{28}$. Aún así, sólo debe ejercitarse en la danza aquel individuo al que «ya su naturaleza, en la distribucion de sus partes personales no anduvo tan esteril que no le concedio instrumentos capazes en que hiziera impression» ${ }^{29}$. El arte no es suficiente, según observa Esquivel de manera coherente con el tópico humanista, para suplir las carencias de la naturaleza.

Si bien la danza virtuosa posee propiedades éticas y resulta tan conforme con la armonía universal como pudieran estarlo las consonancias musicales o un discurso retórico perfectamente compuesto y pronunciado, quedan excluidos sin embargo del contexto edificante los movimientos deshonestos o lascivos ${ }^{30}$. Significativamente, Esquivel apoya sus observaciones en diversas auctoritates convencionales en los tratados musicales humanistas y prerracionalistas, entre ellas la del jesuita Agustín de Roa:

«Y porque mi intento es reprobar (como repruebo) en este Tratado todo movimiento ilicito dançando, o baylando; digo, que toda deshonestidad y descomposturas lascivas del cuerpo, desluze y desdora la persona que las obra; por lo qual los grandes señores dançan tan compuesto y grave. Y pues que en todo desseamos imitarlos, como se ve por las galas y otros usos, pues siempre apetecemos los superiores, razon es imitarlos en esto, siguiendo el asseo y buen modo de dançar destos Principes ${ }^{31}$.

«Y por autorizar tanto este Arte el P. Augustin de Roa de la Compañia de IESUS en el libro que escrivio del estado de los Bienaventurados, en el cap. 13. demuestra parecerle, que en el Cielo se dança, apoyandolo con dichos de Santos. Y el gran doctor de la Iglesia San Geronimo en el cap. 30. del Eclesiastés dize: Llorar debemos porque despues podamos dançar aquellas danças que dançó David ante el Arca del testamento. Y San Augustin en el lib. 22. de Luv. cap. 30. dize, que todos los miembros del cuerpo servirán a las alabanças de Dios. Nuestra Madre la Iglesia en el Hymno del Oficio de las Virgines, dize de N. Redemptor Iesu Christo, que está rodeado de Choros y danças de ellas, que siguendo sus passos

\footnotetext{
${ }^{27}$ ESQUIVEL, Juan de. Discursos sobre el arte del dançado. I, 5r.

28 Ibid.

29 Ibid.

${ }^{30}$ La definición del gesto lascivo al que con tanta frecuencia aluden los moralistas en sus críticas del teatro aurisecular español resulta todavía más difusa en el contexto de la retórica, la poética, la preceptiva dramática y la danza barroca de lo que pudiera resultar hoy en día. Covarrubias define «lascivia» como «lujuria, incontinencia de ánimo, inclinación y propensión a las cosas venéreas, blandas y regaladas, alegres y chocarrescas en esta materia». Es así lascivo aquel que «está afecto a tal pasión o es incitamiento della». La manifestación física que expresaría este afecto son los «meneos del cuerpo descompuestos» (COVARRUBIAS, Sebastián de. Tesoro de la Lengua Castellana. 411).

${ }^{31}$ ESQUIVEL, Juan de. Discursos sobre el arte del dançado. I, 5v-6v.
} 


\begin{abstract}
ligeras, dançavan y cantavan Canciones. Y assi las vio San Juan en su Apocalypsi, seguir al Cordero dançando y cantando una nueva Canción. Dize también la Iglesia, de los Santos niños Inocentes, que ante el Ara de su martyrio se entretienen haziendo mudanças con las Coronas y Palmas. Y pues este exercicio tiene tantos meritos, no será bien que lo reduzgamos a lascivo y deshonesto, siendo él en si virtud» ${ }^{32}$.
\end{abstract}

Frente al empeño de tratadistas como Esquivel en presentar una descripción teórica de la danza tendente a la virtud mediante la reproducción gestual de la perfección ética, la práctica escénica trasciende, también en el terreno de la danza, cualquier pretensión de organización platónica más o menos canónica. Por esta razón, es precisamente en este terreno donde cabe encontrar el mayor nivel de transgresión del decoro afectivo. Y si existe una danza que a lo largo del siglo XVII asuma como propias las cualidades de la deshonestidad y la lascivia, ésta es la zarabanda. La desinformación sobre ella ha sido general prácticamente desde su creación, debido, por una parte, a la escasez de datos coreográficos $\mathrm{y}$, por otra, a su carácter transgresor que la aleja de los cánones de la expresión virtuosa platónica y la acerca sin embargo a la expresión erótica. La asociación de la zarabanda con gestos capaces de despertar las pasiones eróticas resulta ser una constante ya desde sus orígenes documentados, que Robert Stevenson remonta a una mención aparecida en 1579 en la Historia de las Indias de Nueva España del dominico español y misionero en México Fray Diego Durán ${ }^{33}$ En un controvertido artículo en el que equipara esta danza con la jácara, María José Ruiz Mayordomo propone una división de los diversos géneros que se agrupan bajo el nombre de la primera de estas danzas en cuatro grupos principales: la zarabanda poética, que puede identificarse con el zéjel; la zarabanda musical-instrumental compuesta por una estructura rítmico-armónica que se interpretaba con instrumentos, aunque no se cantaba ni se danzaba; la zarabanda lírica, provista de texto y música (o cantar de la zarabanda), aunque no necesariamente compuesta para ser danzada; la zarabanda coreográfica, o danza de la zarabanda propiamente dicha. Es ésta última la que despierta la mayor parte de las críticas de los moralistas debido al supuesto grado de lascivia gestual que desplegaban los bailarines $^{34}$. La interpretación de estas danzas podía tener lugar en entornos privados, como uno más de los repertorios que formaban parte de la educación habitual de la burguesía acomodada y la nobleza durante los siglos XVI y XVII, en el contexto paralitúrgico, caracterizadas generalmente bajo la denominación «a lo divino», o en el contexto dramático, interpretadas por actrices sobre el escenario. La zarabanda coreográfica, tan denostada por los

\footnotetext{
${ }^{32}$ Ibid. I. 5v-6v.

${ }^{33}$ STEVENSON, Robert. «The first dated mention of the sarabande». Journal of the American Musicological Society. Spring, 1952, 5, 1, pp. 29-31.

${ }^{34}$ RUIZ MAYORDOMO, María José. «Jácara y zarabanda son una misma cosa». Edad de Oro. Madrid: Universidad Autónoma, 2003, XXII, pp. 283-307.
} 
moralistas como para haber sido prohibida ya en 1583 y castigada su puesta en escena con 200 azotes, sobrevive sin embargo durante décadas, tanto en España como en otros países europeos. Aunque los tratadistas neoaristotélicos de poética y retórica dedican a la danza un número de observaciones considerablemente menor del que refieren a propósito de la práctica de la música, en la epístola trece de su Philosophía antigua poética de 1596 - la época de mayor aceptación popular de zarabanda-, Alonso López Pinciano sí se refiere en estos términos a la desmesura y deshonestidad gestual características de la zarabanda dramática, en el contexto de un diálogo en el que se discute accidentalmente el asunto de la dignidad de los actores:

«Es la verdad que cierta manera de representantes son viles y infames, que, como
agora los zarabandistas, con movimientos torpes y deshonestos incitaban antigua-
mente a la torpeza y deshonestidad, a los cuales los latinos dieron nombre de
«histriones» y de los cuales se dice estar prohibidos de recebir el sanctíssimo
Sacramento de la Eucharistía. Mas los representantes que los latinos dijeron «ac-
tores», como los trágicos y cómicos ¿por qué han de ser tenidos por infames?,
¿qué razón puede haber para un disparate como ése?» ${ }^{35}$.

También el Padre Juan de Mariana, en el capítulo «De los espectáculos» del tratado De Rege se refiere en 1598 a un «baile y cantar tan lascivo en las palabras, tan feo en los meneos», que basta para escandalizar «aun a las personas muy honestas». Se trata de un tipo de composición que llaman «comunmente zarabanda y dado que se dan diferentes causas y derivaciones de tal nombre ninguna se tiene por averiguada y cierta; lo que se sabe es que se ha inventado en España» ${ }^{36}$. Parece que, en los años finales del siglo XVI, la zarabanda se bailaba tanto en el teatro como en la calle por parte de parejas de hombres y mujeres que representaban una especie de «pantomima sexual» ${ }^{37}$. Los paralelismos de la zarabanda con estrofas de ascendencia árabe como el zéjel, junto con proyecciones retrospectivas del imaginario erótico actual han dado lugar a algunos a pensar que los «feos meneos» a los que se refiere Mariana pudieran consistir en movimientos realizados con las piernas y la cintura que asemejaran el baile a una especie de danza del vientre. Sin embargo, el tipo de vestuario que utilizaban los bailarines -incluso las actricesen el siglo XVII español, compuesto de piezas tan poco cómodas para los movimientos pélvicos como las distintas clases de verdugos o guardainfantes, da lugar a pensar que el tipo de sugerencia erótica que pudieran haber conseguido las bailarinas empleando sólo este tipo de gestos pudiera ser reducido. Por otra parte, de las descripciones de los moralistas se deduce más bien que la sensualidad de la zarabanda derivaba de los movimientos de los brazos de

\footnotetext{
${ }^{35}$ LÓPEZ PINCIANO, Alonso. Philosophía antigua poética, pp. 515-516.

${ }^{36}$ MARIANA, P. Juan de. «De los Espectáculos». De Rege, 1598, cap. XII.

${ }^{37}$ EZQUERRO, Antonio. «Zarabanda». Diccionario de la música española e iberoamericana. Madrid: SGAE, 2002, 10 vol., pp. 1121-1128.
} 
las mujeres. Así, por ejemplo, Sebastián de Covarrubias describe la zarabanda como un baile «alegre y lascivo» porque «se hace con meneos del cuerpo descompuestos», aunque enseguida indica que, a pesar de que estos meneos se llevan a cabo con todas las partes del cuerpo, «los brazos hacen los más ademanes, sonando las castañetas ${ }^{38}$. En 1614 Alonso Cano y Urreta trata de entontrar algún parentesco entre las danzas españolas y sus parientes remotas latinas. Así, según Cano y Urreta, «Achacó Roma este mal a Cádiz y Andalucía; de quien, en vez de saltar varonil y fuerte mudó el baile su perfección en vueltas de brazos y meneos lascivos». Parece ser que la zarabanda «consistía en gestos y movimientos de manos», la chacona «estribaba en los pies», y el escarramán «en quebrar el cuerpo y dar descompuestos saltos» ${ }^{39}$. En $L a$ villana de Xetafe (1620), Lope de Vega proporciona un rápido inventario de las danzas que podían interpretarse en los años centrales del siglo XVII. El valor histórico de las afirmaciones de los personajes resulta solamente relativo. Así, mientras que posiblemente la afirmación de que la zarabanda «estaba muy vieja» resultara verdadera en términos de vigencia temporal, las que realiza a propósito de otras, como el villano, son solamente un juego de palabras en el que interfieren las bromas sobre la condición social de los interlocutores con la genealogía - no con la realidad en el siglo XVII- de una danza que, efectivamente, pudo tener su origen en melodías y movimientos propios de los campesinos. Son juegos tan habituales como las bromas a propósito de las mudanças de las danzas (cada una de las series de movimientos que se danzan sobre una misma composición musical o sobre estrofas o coplas semejantes dentro de ella), muy graciosas seguramente desde la convencional misoginia retórica que considera a las mujeres como seres mudables más allá de todo planteamiento racional:

$\begin{array}{ll}\text { Don Félix } & \text { Ay bella Ynés, si de tu hermosa boca } \\ \text { merezco yo favores tan notables, } & \text { para matarme, basta que me hables, } \\ & \text { y basta para hazer, que aquí me quede } \\ & \text { a servirte, quererte, a acompañarte, } \\ \text { que me des essa luz para mirarte, } \\ \text { ponte las castañuelas, y el donayre } \\ \text { dessos hermosos pies de invidia al ayre, } \\ \text { que mientras bailas tu sin divirtirme, } \\ \text { en tus mudanças estaré yo firme. } \\ \text { Qué es lo que queréis bailar? } \\ \text { Ynés } & \text { Lo que vos sepáis señora. } \\ \text { Martínez } & \text { Bacas }{ }^{40}\end{array}$

\footnotetext{
${ }^{38}$ COVARRUBIAS, Sebastián de. Tesoro de la lengua castellana, 984.

${ }^{39}$ CANO Y URRETA, Alonso. Días de jardín. Madrid: Bernardino de Guzmán, 1619, 40.

${ }^{40}$ Cualquiera de las numerosas variaciones del popular tema del «Guárdame las vacas», como las cuatro diferencias seguidas de tres más «hechas por otra parte», que Luys de Narváez compila en Los seis libros del Delphin de musica en cifra para tañer vihuela, o
} 


\begin{tabular}{|c|c|}
\hline Ynés & $\begin{array}{l}\text { Aunque labradora } \\
\text { dama, no las se vaylar. }\end{array}$ \\
\hline Doña Beatriz & Folías? \\
\hline Ynés & Comunes son \\
\hline Doña Beatriz & Canario? \\
\hline Ynés & Soy toledana \\
\hline Doña Beatriz & Villano? \\
\hline Ynés & $\begin{array}{l}\text { No soy villana } \\
\text { en ingenio y condición. }\end{array}$ \\
\hline Doña Beatriz & Conde Claros? $?^{41}$ \\
\hline Ynés & $\begin{array}{l}\qquad \text { Puede dar } \\
\text { gusto a quien tuviere amores, } \\
\text { si es verdad que con amores } \\
\text { no podía reposar. }\end{array}$ \\
\hline Doña Beatriz & Zarabanda? \\
\hline Ynés & Está muy vieja. \\
\hline Doña Beatriz & Chacona? \\
\hline Ynés & Sátira es. \\
\hline Doña Beatriz & Rey don Alonso? \\
\hline Ynés & $\begin{aligned} & \text { ¿No ves, } \\
\text { que es juntar corona y reja? } & { }^{42}\end{aligned}$ \\
\hline
\end{tabular}

En el siglo XVII, comentaristas como el padre Ignacio Camargo insistirían en sus ataques contra la lascivia en escena, una lascivia que se identifica, casi necesariamente, con la exhibición de la desenvoltura femenina, más acentuada si tiene lugar en forma de danza:

«¿Qué cosa más torpe y provocativa que ver á una muger de esta calidad que estaba ahora en el tablado dama hermosa afeitada y afectada, salir dentro de un instante vestida de galán airoso, ofreciendo al registro de los ojos de tantos hombres todo el cuerpo que la naturaleza misma quiso que estuviese siempre casi todo retirado de la vista? ¿Pues qué sería si en ese traje danzase como lo hacen muchas veces? ¿Cuál estarán los corazones de muchos infelices que las miraron antes y con cuidado en su traje de mugeres? Verdaderamente que esta gente vil y soez pierde el respeto indignamente á la gente grave y seria que compra su deleite á costa de su desprecio...» $»^{43}$.

Aun así, la perspectiva de los moralistas no coincide con la de los defensores de la escena como Francisco Cascales, quien, en sus Cartas philológicas de 1627, se expresa en los siguientes términos:

las cinco diferencias que Luys Venegas de Henestrosa incluye en su Libro de cifra nueva para tecla, harpa y vihuela.

${ }^{41}$ Cualquiera de las variaciones sobre el tema del «Conde Claros», como las veintidós diferencias que Luys de Narváez incluye en Los seis libros del Delphin de musica en cifra para tañer vihuela.

${ }^{42}$ LOPE DE VEGA, La villana de Xetafe. Parte catorze de las comedias de Lope de Vega Carpio. Madrid: Iuan de la Cuesta, 1620, ff. 26v-55. Díez Borque, José María (Ed. facs.). Madrid: Orígenes, 1990.

${ }^{43}$ CAMARGO, P. Ignacio. Discurso theologico sobre los theatros y comedias de este siglo. Salamanca: Lucas Pérez, 1689, pp. 124. 
«Supuesto, pues, que hoy se representan sin deshonestidad, se danza sin movimientos irritantes y se canta tan modestamente como vemos, no ha lugar la ley que los amenaza; (...) oir comedias ó representarlas ó consentirlas no es pecado mortal, no siendo las representaciones bailes y cantares torpes y lascivos, aunque las comedias sean profanas, y aunque representen mujeres, y aunque éstas se vistan en hábito de hombres» ${ }^{4}$.

El optimismo crítico de Cascales escapa de la realidad de la escenificación de las comedias en los años centrales del siglo XVII, o, al menos, no debía de responder al mismo concepto de honestidad que manejaban los defensores de la rectitud estética de la escena. De otra manera no se entiende que el Consejo de Castilla dictara en 1644 las normas siguientes, insistiendo en la contención en los gestos de las mujeres y en la supresión de toda danza que pudiera considerarse indecente, desgarrada o inmodesta. Llama la atención que, si bien se menciona de manera explícita el nombre de danzas como la jácara, la sátira o las seguidillas, no se nombre en ningún momento la danza más denostada de todas: la zarabanda; más aún cuando, como se verá enseguida, todavía en 1691 la comentarista francesa Marie Catherine de Aulnoy se refiere en sus escritos a cómo vio a mujeres interpretando esta danza: ${ }^{45}$

«IV. Que se moderasen los trajes de los comediantes, reformándose los guardainfantes de las mujeres, el degollado de la garganta y espalda, y que en las cabezas no sacasen nuevos usos ó modas, sino la compostura del pelo que se usase. VI. Que no se cantasen jácaras, ni sátiras, ni seguidillas, ni otro ningún cantar ni baile antiguo ni moderno, ni nuevamente inventado que tuviere indecencia, desgarro ni acción poco modesta, sino que usasen de la música grave y de los bailes de modestia, danzas de cuenta y todo con la mesura que en teatro tan público se requería, y que los cantares y bailes que tuviesen alguna representación no se pudiesen decir ni hacer sin que estuviesen pasados y registrados por el Comisario del Consejo.

VII. Que ninguna mujer, aunque fuese muchacha, bailase sola en el teatro, sino en compañía de otras, y si el baile fuese de calidad que se hubiesen de poner cerca hombres y mujeres, fuese con acción y modo muy recatado.

VIII. Que no pudiese bailar, ni cantar, ni representar mujer ninguna que no fuese casada, como se había mandado ${ }^{46}$.

Marie Catherine d'Aulnoy, en su Relation du Voyage d'Espagne, se sorprende al encontrar a las intérpretes de la zarabanda «deslizándose» por el

${ }^{44}$ CASCALES, Francisco. «Epist. $3^{\text {a }}$. Al Apolo de España, Lope de Vega Carpio. En defensa de las comedias y representación de ellas. Cartas philológicas». Es a saber, de letras humanas, Varia erudición, Explicaciones de Lugares, Lecciones curiosas, Documentos poéticos, Observaciones, ritos i costumbres, i muchas sentencias exquisitas. Murcia: Luis Veros, 1634.

${ }^{45}$ Otra explicación de la ausencia del nombre de la zarabanda sería la identidad o confusión con la jácara a la que se refiere María José Ruiz Mayordomo en su artículo. RUIZ MAYORDOMO, María José. «Jácara y zarabanda son una misma cosa».

${ }^{46}$ COTARELO Y MORI, Emilio. Bibliografía de las controversias sobre la licitud del teatro en España. Madrid: Tipografía de la Revista de Archivos, Bibliotecas y Museos, 1904. 143. 
suelo, aunque siguiendo el ritmo con los brazos y subrayándolo además con las castañuelas. Y no es el movimiento de los brazos en sí lo que desconcierta a la viajera francesa, sino el hecho de que, contrariando la práctica general en la danza barroca de limitar el alzado de los brazos a los movimientos que es posible llevar a cabo sin que las manos superen la altura de las clavículas, estas bailarinas eleven sin embargo las suyas por encima incluso de la cabeza.

«Las actrices traían castañuelas y usaban pequeños sombreros. Es costumbre cuando bailan, y cuando danzan la zarabanda, parecer que no tocan el suelo, de lo ligero como se deslizan. El estilo es bastante diferente al nuestro; mueven sus brazos muchísimo y con frecuencia elevan sus manos sobre su cabeza y el rostro con arrebatadora gracia, tocando las castañuelas admirablemente» ${ }^{47}$.

Es, una vez más, la ruptura de la norma gestual decorosa - la de la descripción incluso física de una línea capaz de separar el espacio gestual del decorum del territorio de la transgresión erótica- la que, mediante un efecto de desviación retórica plenamente disonante con la armonía gestual que defienden los teóricos humanistas y racionalistas, permite la entrada al mundo de la libertad expresiva y de la referencia sexual. Y es, una vez más, la gestualidad femenina la más atractiva según el gusto de observadores como Aulnoy, así como la que más ofensiva parece resultar desde el punto de vista de los moralistas:

Francisco Bances Candamo, en su Theatro de los theatros de $1694 *, 48$ compuesto contra los excesos críticos de los moralistas medievales y contemporáneos y, especialmente, contra las obsesiones anti-lascividad de Ignacio Camargo, proporciona algunos de los datos más explícitos sobre unos bayles lascivos de Cádiz descritos por Marcial y Juvenal que, a todos los efectos, tanto terminológicos como coreográficos, pueden clasificarse como una especie de zarabandas arcaicas dotadas, ya entonces, del mismo significado supuestamente lascivo que adquirirían las del siglo XVII. Bances Candamo insiste en observar la expresión de los afectos mediante gestos corporales y, especialmente, mediante gestos de las manos (chironomias):

«En estos mismos Juegos y Juvenales se introdugeron al tablado los lascivos bailes de Cádiz, como dice el mismo Alexandro. Eran éstos tan deshonestos como sobre los Epigrammas de Marcial, que se referirán aquí, se podrá ver en sus Intérpretes Domicio Calderino, Theodoro Marcillio y don Lorenzo Ramírez de Prado. Eran obscenas las canciones y mucho más los movimientos, de que Marcial y Iuvenal dan bien individuales señas. Marcial dice así en uno de sus Epigrammas:
«Ni de los deshonestos Gaditanos Vibrarán las muchachas (encendidos en bulliciosa comezón de fuego) con un dócil temblor lomos lascivos».

${ }^{47}$ D'AULNOY, Marie Catherine. Relación del viaje de España (1691). Madrid: Akal, 1986, 62.

${ }^{48}$ Terminus ante quem. 
Hablando después de Thelesina, aquella insigne bailarina de Cádiz, tan diestra en este género de movimientos impúdicos, dixo:
«Diestra en los gestos lascivos
y en cantar los metros diestra
de Cádiz, quando repica
la Andaluza castañeta».

El mismo, en otro Epigrama escrito de intento a otra Bailarina de Cádiz, buelve a dar esta noticia de aquel género de baile:
«Tan trémula en sus quiebros vibra diestra los muslos, y tan tierna hace bullicios de cosquillosa comezón que hiciera al mesmo casto Hippólito impúdico».

\begin{abstract}
Aún tiene más claridad el verso Latino, y aún tenemos en Iuvenal señas de este baile en estos versos del margen, que por ser aún más claros no traduzgo, no obstante que tengo por preciso no callar nada, por torpe que sea, del theatro antiguo y moderno, pues los mismos santos lo dicen y le es preciso al fin de esta obra. De aquí se colige claro ser estos bailes de Cádiz, que se hacían en el tablado, como los que aún oi permanecen de zarambeque, guineo y otros, con algo de menos embozo, pues estos versos de Iuvenal expressan en ellos lo último de la deshonestidad. Alexandro divide después estos bailes en Chironomias, que era bailar haciendo gestos con las manos, en Halmas, que era con maior velocidad de los pies, y en Lactismas, que eran bailes que hacían con los calzados sobre los hombros...» ${ }^{49}$.
\end{abstract}

Las observaciones de Bances Candamo sobre el parentesco de las danzas de Cádiz con otras de procedencia africana como el zarambeque y el guineo dan lugar a pensar que pudiera existir una línea continua que fuera desde los bailes basados en el uso de castañuelas o castañetas, en la composición alternativa de quironomías, en el veloz movimiento de los pies que tanto impresiona a Marie Catherine d'Aulnoy o en la práctica de gestos provistos de connotaciones eróticas hasta los distintos tipos de baile flamenco que solamente con dificultad ha podido datarse en momentos anteriores a la segunda mitad del siglo XVIII.

J. Ignacio Díez Fernández reproduce una zarabanda poética en la que los tópicos de la guerra de amor, la disonancia musical y hasta el estribillo característico de la zarabanda «a la matadora, a la perra mora» rodean la representación de un encuentro sexual plagado de símbolos tan obvios que harían feliz a cualquier psicoanalista, desde el puñal representando el pene masculino hasta el broquel como trasunto de la vagina. Lo que no resulta tan frecuente es la asociación explícita entre la representación de lo erótico y la disonancia musical a la que se refiere el segundo cuarteto: «El que no fuere amador/no

${ }^{49}$ BANCES CANDAMO, Francisco. Theatro de los theatros de los passados y presentes siglos. Tercera versión. 109-110. 
me escuche aunque yo cante/ que destemplara el discante/ la prima, baxo y tenor.» ${ }^{50}$ Heredero de la tradición provenzal y cancioneril de la guerra de amor continuada en los siglos siguientes por la estética italiana petrarquista y por la tradición retórico-musical madrigalística, el poema presenta, sin embargo, un grado de referencia erótica muy propio del cantar - y del danzar- de la zarabanda. La interferencia de códigos no sólo tiene lugar en este caso entre el lenguaje del encuentro amoroso y el de la guerra, sino que se extiende a los siempre conflictivos sistemas de coherencia de la rectitud virtuosa - reflejada, de manera más o menos sincera, en la rectitud social- y de la catarsis erótica y afectiva. El ámbito de la virtud convencional y el del erotismo son universos paralelos que se perciben recíprocamente como disonantes: precisamente el mismo efecto auditivo que enfrenta en la Italia del XVII a los partidarios de la polifonía compuesta según las reglas de la inteligibilidad y la consonancia defendidas por Zarlino con los defensores del atrevimiento estilístico basado en la introducción de la disonancia como factor retórico relativo a unos afectos catárticos cada día más próximos a la desmesura pasional y al erotismo poético.

La misma disonancia o destemplanza que, en contextos teóricos, da lugar a los tratadistas a remitirse a la desviación con respecto a la línea recta de la virtud aparece con sospechosa frecuencia asociada con el gesto bélico-amoroso. El tópico de la muerte erótica — «en esta guerra de amor/ el que muere es vencedor ${ }^{51}$ - , equivalente decorosa del orgasmo, surge en esta zarabanda y en otras obras dentro del repertorio lírico español tanto como pueda figurar

${ }^{50}$ El cantar procede de los folios 42 v.-44 v. [texto 21.289 de la Bibliografía de la Poesía Áurea (BIPA)]. Cf. DÍEZ FERNÁNDEZ, J. Ignacio. La poesía erótica de los Siglos de Oro. Madrid: Laberinto, 2003. J. Ignacio Díez Fernández analiza la expresión del erotismo en la poesía española del Siglo de Oro y en sus antecedentes medievales como una forma de superación del platonismo poético. Observa también la tradicional ignorancia, real o fingida, a la que la perspectiva moralista característica de una parte de la crítica académica sometió a este repertorio hace ya algunas décadas. DÍEZ FERNÁNDEZ, J. Ignacio. «¿Erotismo o pornografía?». La poesía erótica de los Siglos de Oro. Madrid: Laberinto, 2003. pp. 19-25.

Las formas de puritanismo crítico son innumerables, tanto desde el punto de vista cronológico como desde el geográfico, y resultan tan dignas de crítica como las posibilidades de despojar la experiencia sexual de todo contenido afectivo que revelan numerosas muestras de literatura erótica. En el contexto humanista de inspiración italiana, tanto en su dimensión musical como en la textual, la exploración lírica del erotismo supondría transgredir los límites del petrarquismo poético, con su sublimación recurrente de los aspectos físicos de la experiencia amorosa y la consideración del estrato erótico como equivalente a la degradación de los afectos. El que autores como Orlando di Lasso en sus madrigales eróticos o, de manera más estilizada todavía y conforme ya con las audacias retóricas de la seconda prattica, Monteverdi y Maurizio Moro en el madrigal Si ch'io vorrei morire se atrevan a poner los medios del contrapunto madrigalístico al servicio de la retórica sexual supone asî un grado de valentía poética inusitado en el contexto del platonismo petrarquista y del culto a la consonancia propio de la escuela de Zarlino.

${ }^{51}$ Ibid. 19-25. 
dentro de la tradición italiana, en obras tan características de la retórica musical de la seconda prattica como el madrigal Sì, ch'io vorrei morire del Libro IV de Claudio Monteverdi. En ambos casos, la expresión de la muerte erótica aparece decorada afectivamente mediante efectos directamente relacionados con la teoría de la qualitas sonorum. En el caso del madrigal de Monteverdi, las exclamaciones («Ahi», «Deh», «Ah» y el adverbio «Si» que enfatiza la proposición «ch'io vorrei morire») cumplen así, más allá del terreno semántico o de las necesidades rítmicas de cada verso, una función significativa también en el nivel fónico:

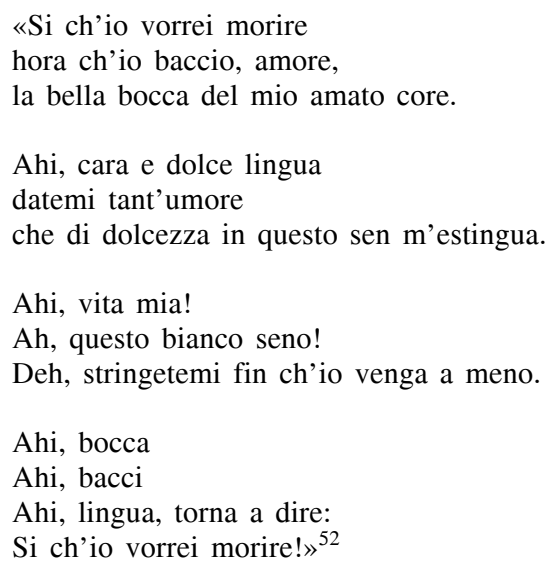

El poema de Mauritio Moro que Claudio Monteverdi pone en música no podría resultar menos decoroso en un momento en el que el universo petrarquista recomienda las alabanzas más distantes a la belleza de la dama, excluyendo toda posibilidad de acercamiento físico. La gradatio cromática en la decoración del creciente grado de proximidad de los amantes mediante la palabra poética — «Ahi, bocca / Ahi, bacci / Ahi lingua...»— cuenta con un paralelo simétrico en su versión descendente, subrayando las cláusulas que indican un descenso en el contacto afectivo: «datemi tant'umore/ che di dolcezza in questo sen m'estingua» $\mathrm{o}$ «Deh, stringetemi fin ch'io venga a meno». Si la expresión de la proximidad física quedaba relegada a la poesía erótica - el estrato poético más inconveniente en el contexto petrarquista—, tanto la referencia explícita a la consumación sexual o a los humores y partes del cuerpo que participan en ella como el uso de la disonancia y el cromatismo sitúan claramente el madrigal dentro de los confines de la seconda prattica. La exploración del recurso de la amplificatio retórica en la entrada gradual de las

52 «Poema de Mauritio» Moro puesto en música por Claudio Monteverdi. En MONTEVERDI, Claudio. Libro IV de Madrigali a cinque voci (1603), Tutte le opere. En MALIPIERO, G. Francesco (ed.). Venecia, 1966, 17 vols. 
voces que repiten el texto «Ahi cara e dolce lingua» a distancia de un tono ascendente y su posterior versión descendente marcan los flujos y reflujos retóricos en el éxtasis amoroso hasta la repetición final de la proposición «si ch'io vorrei morire» que cierra formalmente en forma de círculo el madrigal.

Las consecuencias éticas del uso de la disonancia en un momento en el que la estética petrarquista basada en la idea de concordia en el terreno literario convive con la reverencia a la norma polifónica zarliniana basada en la consonancia parecen evidentes. Sin embargo, la división entre los campos enfrentados de la virtud y del erotismo iría diluyéndose en toda Europa a partir de los primeros años del siglo XVI, cuando comienza la difusión de la crítica racionalista, tanto en su versión laica, representada luego por la literatura cartesiana, como en la espiritualista, presente fundamentalmente en las obras de Athanasius Kircher y de sus contemporáneos o receptores ${ }^{53}$. Las pasiones adquieren así una nueva consideración como parte del universo del decoro poético, antes circunscrito a los afectos coherentes con la norma ética vigente. Esta misma legitimación de lo pasional, junto con el desarrollo en los medios expresivos y técnicos que permitían la puesta en escena del drama musical y de otras maneras de poner la palabra en música tuvo lugar en el terreno del discurso musical a medida que algunos intervalos considerados inicialmente como disonantes fueron adquiriendo la consideración consonante, mientras que el uso de aquellos otros que seguían manteniendo su carácter disonante se fue convirtiendo en un aspecto más del paradigma del decoro compositivo. Igualmente, las constricciones gestuales presentes en la danza de los siglos XVI y XVII que con tanta alegría insisten en romper actrices y bailarinas profesionales o populares para disgusto de los moralistas van dando paso a un discurso danzado cada vez más libre y más coherente con una consideración positiva del cuerpo que, aunque sea con altibajos, se extiende por Europa desde entonces hasta nuestros días. Las disonancias musicales, literarias o gestuales nunca perderían, sin embargo, su poder retórico para poner de manifiesto aquellas emociones que resultan de la incoherencia o de la ruptura de los distintos tipos de decoro afectivo derivados de las sucesivas nociones convencionales de

${ }^{53}$ La equiparación entre la disonancia musical y sus correspondencias gestuales aparece detallada en esta cita en la que el jesuita Athanasius Kircher describe una representación similar al homo quadratus de Vitrubio: «Iterum sicut unisonus principium pulchritudinis \& harmonie; ita si horum trium quodlibet aequisonantem proportionem non servaverit, statim nescio quid dissonum foedum, pulchritudinis \& harmoniae destructivum emergit, ut in iis hominibus, quibus frons aut productior, nasusque contractior; aut frons contractior, nasusque longior aequo existit, apparet. Idem reperies in coeteris membrorum proportionibus, ut in adiuncta figura patet. In qua vides quoque hominem perfectissimum quadrato, circuloque essemplici membrorum habitu; si enim manus pedesque divaricatos, quantum potest, in formam crucis Andreanae accommodet, erit centrum circuli extrema manuum pedumque tangentis ipse umbilicus.» KIRCHER, Athanasius. Musurgia universalis sive ars magna consoni et dissoni in X libros digesta. Roma: Typographia Haeredum Francisci Corbelletti, 1650. X, I, 407. 
bien común que venimos pretendiendo desde que Aristóteles compusiera su teoría poética hasta nuestros días.

\section{REFERENCIAS BIBLIOGRÁFICAS}

Fuentes primarias

ARISTÓTELES. Ethica Nicomachea. Oxford: Clarendon, 1962, Ética a Nicómaco. (Ed. española). Madrid: Gredos, 1985).

—. De anima. Oxford: Clarendon, 1956.

—. Parva naturalia. Oxford: Clarendon, 1955.

AULNOY, Marie Catherine d' Relación del viaje de España (1691). Madrid: Akal, 1986.

BANCES CANDAMO, Francisco. Theatro de los theatros de los passados y presentes siglos (1692-1694*). Moir, Duncan W. (ed.). Londres: Tamesis Books, 1970.

CACCINI, Giulio. Le nuove musiche. Florencia: Marescotti, 1601. (Ed. facs. Florencia: Spes, 1982).

—. Nuove musiche e nuova maniera di scriverle. Florencia: Zanobi Pignoni, 1614. (Ed. facs. Florencia: Spes, 1983).

CANO Y URRETA, Alonso. Días de jardín. Madrid: Bernardino de Guzmán, 1619.

CARAMUEL, Juan. Trismegistus Theologicus latine cuius tomi sunt tres, in quibus tres virtuales et morales maximae, quae subcollant Restrictionum doctrinam radicitux edisseruntur, Earum est... PRIMA, Restrictiones sensibiles... ПOА YMNEIA (Multiloquens nominatur); SECUNDA, Restrictiones insensibiles... $\Sigma I \Gamma A \Lambda I \Omega N$ (Harpocrates dicitur); TERTIA, AПИOTH $\Sigma$ (Sinceritas, certissimis \& clarissimis analogismis demonstratur), Vigebano, Typis Episcopalibus apud Camillum Conradam, 1679.

CASCALES, Francisco. «Epist. $3^{\mathrm{a}}$. Al Apolo de España, Lope de Vega Carpio. En defensa de las comedias y representación de ellas. Cartas philológicas». Es a saber, de letras humanas, Varia erudición, Explicaciones de Lugares, Lecciones curiosas, Documentos poéticos, Observaciones, ritos i costumbres, i muchas sentencias exquisitas. Murcia: Luis Veros, 1634.

CASTIGLIONE, Baltasar de. El Cortesano (1534). Boscán, Juan de (trad.); Reyes Cano, Rogelio (ed.). Madrid: Espasa-Calpe, 1984.

CAUSSIN, Nicolas. Eloquentiae sacrae et humanae parallela. libri XVI. París: S. Chappelet, 1619.

CERONE, Pietro. El Melopeo y Maestro, Tractado de música theorica y practica, en que se pone por extenso, lo que uno para hazerse perfecto Musico ha menester saber, y por mayor facilidad, comodidad y claridad del Lector, esta repartido en XXII Libros. Nápoles: Juan Bautista Gargano y Lucrecio Nucci, 1613.

CICERÓN, De Oratore. Cambridge: Harvard University Press. Londres: William Heinemann, 1968.

—. Rhetorica, De Oratore. Oxford: Clarendon, 1963.

-. Sobre el Orador. Madrid: Gredos, 2002.

—. De inventione. Madrid: Gredos, 1997.

FRESCOBALDI, Girolamo. Arie musicali. Florencia: G.B. Landini, 1630, 2 vols. (Ed. facs. Florencia: Spes, 1982).

FUENLLANA, Miguel de. Orphenica lyra. Sevilla: 1554. Jacobs, Charles (ed.). Oxford: Clarendon Press, 1978).

GALILEI, Vincenzo. Dialogo della Musica Antica et della Moderna. Florencia: Giorgio Marescotti, 1581.

RLit, 2009, enero-junio, vol. LXXI, n. ${ }^{\circ} 141,57-84$, ISSN: 0034-849X 
KIRCHER, Athanasius. Musurgia universalis sive ars magna consoni et dissoni in X libros digesta. Roma: Typographia Haeredum Francisci Corbelletti, 1650.

LÓPEZ PINCIANO, Alonso. Philosophía antigua poética (1596). Rico Verdú, José (ed.). Madrid: Fundación José Antonio de Castro, 1998.

LORENTE, Andrés. El por qué de la música en que se contiene los quatro artes de ella, canto llano, canto de organo, contrapunto, y composición, y en cada uno de ellos nuevas reglas, razón abreviada, en utiles preceptos, aun en las cosas más difíciles, tocantes à la Harmonia Música. Alcalá de Henares: Nicolàs de Xamares, 1972; González Valle, José Vicente (ed. facs). Barcelona: CSIC, 2002.

MINTURNO, Antonio Sebastiano. L'arte poetica.Venecia: G. Andrea Valvassori, 1564

MUDARRA, Alonso. Tres libros de música para vihuela. Sevilla: Juan de León, 1546.

NASSARRE, Pablo. Escuela música según la práctica moderna. Zaragoza: Herederos de Diego Larumbe, 1724 y 1723, 2 vols. (Ed. facs. Zaragoza: Institución Fernando el Católico (CSIC), 1980).

QUINTILIANO, Arístides. De musica. Colomer, Luis; Gil, Begoña (ed. esp.). Madrid: Gredos, 1996, III, 24 pp.

TASSO, Torquato. Dialoghi. Ezio, Raimondi (ed.). Florencia: Sansoni, 1958.

—. Dialoghi. Baffetti, Giovanni (ed.); Rizzoli, Giovanni (intr.). Milano, 1998, 2 vols., II, pp. 669-728.

VEGA, Félix Lope de. La villana de Xetafe, Parte catorze de las comedias de Lope de Vega Carpio. Madrid: Iuan de la Cuesta, 1620, ff. 26v-55; Díez Borque, José María (ed. facs.). Madrid: Orígenes, 1990.

ZARLINO DA CHIOGGIA, Gioseffo. Le Istitutioni Harmoniche; Nelle quali; oltra le materie appartenenti alla musica; Si trovano dichiarati molti luoghi di Poeti, d'Historici, \& di Filosofi; Si come nel leggerle si potrà chiaramente vedere. Venecia: ?, 1558; (ed. facs. de la edición de 1573 en Nueva York: Gregg Press, 1966.

—. Dimostrationi harmoniche (...) nelle quali ralmente si trattano le cose della Musica, \& si risolvono molti dubii d'importanza. Venecia: Francesco dei Franceschi Senese, 1571.

—. Sopplimenti musicali (..,) Nei quali si dichiarano molte cose contenute nei due primi volumi, delle Istitutioni \& Dimostrationi; per essere state mal'intese da molti; \& si risponde insieme alle loro Calonnie. Venecia: Francesco de'Franceschi, 1588.

\section{Fuentes secundarias}

BUTLER, Judith. Bodies That Matter: on the Discursive Limits of Sex. Nueva York: Routledge, 1990.

CALCAGNO, Mauro. «Signifying Nothing: on the Aesthetics of Pure Voice in Early Venetian Opera». Journal of Musicology. Fall, 2003, 20, 4, pp. 461-497.

CARAPEZZA, Emilio. «Tasso e la seconda pratica». Tasso, la musica, i musicisti. Balsano, Maria Antonella y Walker, Thomas (eds.). Florencia: Olschki, 1988, pp. 1-15.

ECO, Umberto. «La ligne et le labyrinthe, les structures de la pensée latine». DUBY, Georges (ed.). Civilisation latine. París: Olivier Orban: 1986, pp.27-57.

DEVOTO, Daniel. «La folle Sarabande». Revue de musicologie, 1960, Jul., 45e, 121e, pp. 3-43.

DÍEZ FERNÁNDEZ, J. Ignacio. La poesía erótica de los Siglos de Oro. Madrid: Laberinto, 2003.

EZQUERRO, Antonio. «Zarabanda». Diccionario de la música española e iberoamericana. Madrid: SGAE, 10 vols., 2002, pp. 1121-1128.

FESTINGER, Leon; RIECKEN, Henry W.; SCHACHTER, Stanley. When Prophecy Fails. A Social and Psychological Study of a Modern Group that Predicted the End of the World. Minneapolis: University of Minnesota Press, 1956. 
FISKE, George C. Cicero's «De Oratore» and Horace's «Ars Poetica». Wisconsin: Madison, 1929.

GARCÍA BERRIO, Antonio. Formación de la teoría literaria moderna. Tópica horaciana. Renacimiento europeo. Madrid: Cupsa, 1977.

—. Introducción a la poética clasicista. Madrid: Taurus, 1988.

—. «Poética e ideología del discurso clásico». En Revista de Literatura. Madrid: CSIC, 1979, LXI, 81, pp. 501-527.

GARGANO, Antonio. «Bembo, Garcilaso e la retorica delle fiamme». Fonti, miti, topoi, Cinque studi su Garcilaso. Nápoles: Liguori, 1988, pp. 82-106.

GARRIDO GALLARDO. Miguel Ángel (ed.). Retóricas españolas del siglo XVI escritas en latín '[CD-ROM]. Madrid: CSIC, 2004.

GRIFFITHS, John. «Luis Milán, Alonso Mudarra y la canción acompañada». Edad de Oro. Madrid: Universidad Autónoma, 2003, XXII, pp. 7-28.

- . «The Vihuela, Performance Practice, Style and Context». Lute, Guitar and Vihuela, Historical Performance and Modern Interpretations. Cambridge: Cambridge University Press, 1997, pp. 158-179.

HAMMERSTEIN, Reinhold. Diabolus in Musica, Studien zur Ikonographie der Musik im Mittelalter. Bern: Francke Verlag, 1974.

KNIGHTON, Tess. «The a Cappella Heresy in Spain, An Inquisition into the Performance of the Cancionero Repertory». Early Music, 1992, XX, pp. 345-60.

MARTÍN GALÁN, Jesús. «Juan del Encina». Diccionario de la Música Española e Hispanoamericana, Madrid: SGAE, 1999, (10 vols.), 4, pp. 665-669.

McCLARY, Susan. Feminine Endings, Music, Gender and Sexuality. Minnesota: University of Minnesota Press, 1991.

MORESCHINI, Claudio. «Osservazioni sul lessico filosofico di Cicerone». Ann. Scuola Normale Superiore di Pisa, 1979, pp. 99-178.

NAVARRETE, Ignacio. Los huérfanos de Petrarca. Cortijo, Antonio (vers. esp.). Madrid: Gredos, 1997.

RICO, Francisco. El pequeño mundo del hombre. Madrid: Alianza, 1986.

—. El sueño del Humanismo. Madrid: Alianza, 1993.

ROBLEDO ESTAIRE, Luis. "Gemido del aire, nostalgia del centro, Música, silencio y cosmos en la emblemática española de los Siglos de Oro». Florilegio de estudios de emblemática, Actas del VI Congreso Internacional de Emblemática de The Society for Emblem Studies. La Coruña: Sociedad de Cultura Valle Inclán, 2004.

RUBIO, Samuel. Historia de la música española desde el «ars nova» hasta el 1600. Madrid: Alianza, 2004.

RUIZ MAYORDOMO, María José. «Jácara y zarabanda son una misma cosa». Edad de Oro. Madrid: Universidad Autónoma, 2003, XXII, pp. 283-307.

SCHECHNER, Richard. The Future of Ritual, Writings on Culture and Performance. Nueva York: Routledge, 1993.

STEVENSON, Robert. «The first dated mention of the sarabande». Journal of the American Musicological Society. Spring, 1952, 5, 1, pp. 29-31.

VEGA RAMOS, María José. El secreto artificio, Maronolatría y tradición pontaniana en la poética del Renacimiento. Madrid: CSIC/Universidad de Extremadura, 1992.

Fecha de recepción: 25 de marzo de 2008

Fecha de aceptación: 25 de noviembre de 2008 